\title{
Linoleic Acid and Its Metabolites, Hydroperoxyoctadecadienoic Acids, Stimulate c-Fos, c-Jun, and c-Myc mRNA Expression, Mitogen-activated Protein Kinase Activation, and Growth in Rat Aortic Smooth Muscle Cells
}

Gadiparthi N. Rao, R. Wayne Alexander, ${ }^{*}$ and Marschall S. Runge

Division of Cardiology, University of Texas Medical Branch, Galveston, Texas 77555; and *Emory University School of Medicine, Atlanta, Georgia 30322

\begin{abstract}
Previous studies from other laboratories suggest that linoleic acid and its metabolites, hydroxyoctadecadienoic acids, play an important role in modulating the growth of some cells. A correlation has been demonstrated between hydroxyoctadecadienoic acids and conditions characterized by abnormal cell growth such as atherosclerosis and psoriasis. To determine if linoleic acid and its metabolites modulate cell growth in atherosclerosis, we measured DNA synthesis, protooncogene mRNA expression, and mitogen-activated protein kinase (MAPK) activation in vascular smooth muscle cells (VSMC). Linoleic acid induces DNA synthesis, c-fos, c-jun, and c-myc mRNA expression and MAPK activation in VSMC. Furthermore, nordihydroguaiaretic acid, a potent inhibitor of the lipoxygenase system, significantly reduced the growth-response effects of linoleic acid in VSMC, suggesting that conversion of linoleic acid to hydroperoxyoctadecadienoic acids (HPODEs) is required for these effects. HPODEs also caused significant induction of DNA synthesis, protooncogene mRNA expression, and MAPK activation in growth-arrested VSMC, suggesting that linoleic acid and its metabolic products, HPODEs, are potential mitogens in VSMC, and that conditions such as oxidative stress and lipid peroxidation which provoke the production of these substances may alter VSMC growth. (J. Clin. Invest. 1995. 96:842-847.) Key words: atherosclerosis • DNA synthesis • mitogen-activated protein kinases - polyunsaturated fatty acid $\cdot$ protooncogene expression
\end{abstract}

\section{Introduction}

Linoleic acid, a cis-polyunsaturated fatty acid and the precursor for the synthesis of hydroperoxyoctadecadienoic acids (HPODEs), ${ }^{1}$ has been shown to play a role in modulating growth in various carcino-

Address correspondence to Gadiparthi N. Rao, Division of Cardiology, University of Texas Medical Branch, 9.138 MRB, Route 1064, 301 University Blvd., Galveston, TX 77555-1064. Phone:409-747-1851; FAX:409-747-0692.

Received for publication 10 February 1995 and accepted in revised form 11 May 1995.

1. Abbreviations used in this paper: AP-1, activator protein-1; HPODEs, hydroperoxyoctadecadienoic acids; MAPK, mitogen-activated protein kinases; NDGA, nordihyroguaiaretic acid; VSMC, vascular smooth muscle cells.

J. Clin. Invest.

(c) The American Society for Clinical Investigation, Inc. 0021-9738/95/08/0842/06 $\$ 2.00$

Volume 96, August 1995, 842-847 genic cell types $(1,2)$. In particular, linoleic acid stimulates growth of rat hepatoma cells (1) and enhances the proliferative responsiveness of mammary epithelial cells and fibroblasts to insulin and EGF, respectively $(2,3)$. Conversely, other investigators have found that inhibitors of the lipoxygenase pathway exhibit antiproliferative properties in a large number of cell types $(4,5)$. An association between lipoxygenase-dependent metabolites of linoleic acid and psoriasis has been demonstrated (6). Together, these related findings imply that linoleic acid and its metabolites may play an important role in regulating cell growth in certain cell types.

Vascular smooth muscle cell (VSMC) growth (hyperplasia and hypertrophy) is an important component in the initiation and progression of atherosclerosis and restenosis after angioplasty (7). Increased amounts of hydroxyoctadecadienoic acids (HODEs) and hydroxyeicosatetraenoic acids (HETEs), the lipoxygenase-dependent metabolites of linoleic and arachidonic acids, respectively, have been reported in atherosclerotic arteries (8). Because HODEs and HETEs are growth modulators in many other cell types and the concentrations of these substances are reportedly increased in atherosclerotic arteries, we hypothesized that these products of linoleic and arachidonic acids may be involved in the alteration of VSMC growth in atherosclerosis. We tested this hypothesis by determining the effects of linoleic acid and HPODEs on early growth-response events such as expression of c-fos, c-jun, and c-myc protoocongene mRNA and activation of mitogen-activated protein kinases (MAPK), and late mitogenic events such as DNA synthesis and cell numbers in VSMC. Induced expression of c-fos, c-jun, and c-myc mRNA and activation of MAPK are part of the early response events to a variety of growth stimuli (9-14). In this report, we provide evidence for the first time that linoleic acid and its metabolites, HPODEs, stimulate c-fos, c-jun, and c-myc mRNA expression, MAPK activation, and DNA synthesis induction in VSMC. Linoleic acid and HPODEs also increased VSMC numbers. These results suggest that polyunsaturated fatty acids such as linoleic acid and its metabolites, HPODEs may be important in the altered growth of VSMC in atherosclerosis and other vascular diseases such as restenosis.

\section{Methods}

Materials. Aprotinin, benzamidine, calmidazolium, EDTA, EGTA, $\beta$ glycerophosphate, leupeptin, linoleic acid, myelin basic protein, pepstatin A, PMSF, and sodium orthovanadate were obtained from Sigma Chemical Co. (St. Louis, MO). [ $\left.\alpha^{32} \mathrm{P}\right]-\mathrm{dCTP}(3,000 \mathrm{Ci} / \mathrm{mmol})$ and [methyl ${ }^{3} \mathrm{H}$ ] thymidine $(20 \mathrm{Ci} / \mathrm{mmol})$ were from New England Nuclear (Boston, MA). [ $\left.\gamma-{ }^{32} \mathrm{P}\right]$ ATP $(5,000 \mathrm{Ci} / \mathrm{mmole})$ was obtained from Amersham Corp. (Arlington Heights, IL). ERK-1 and ERK-2 anti-rabbit antibodies were bought from Santa Cruz Biotechnology Inc. (Santa Cruz, CA). Hydroperoxyoctadecadienoic acids (HPODEs) were from Cayman Chemical Company (Ann Arbor, MI).

Cell culture. VSMC were isolated from the thoracic aortae of 200$250 \mathrm{gram} / \mathrm{male}$ Sprague-Dawley rats by enzymatic dissociation as de- 
scribed elsewhere (15). Cells were grown in DME supplemented with $10 \%$ ( vol/vol) heat-inactivated calf serum, $200 \mathrm{U} / \mathrm{ml}$ penicillin and 100 $\mu \mathrm{g} / \mathrm{ml}$ streptomycin. Cultures were maintained in humidified $95 \%$ air $/$ $5 \% \mathrm{CO}_{2}$ at $37^{\circ} \mathrm{C}$ by passage of $1-3 \times 10^{5}$ cells $/ \mathrm{ml}$ on reaching confluence. For all experiments, cells at $70-80 \%$ confluence were made quiescent by incubation for $72 \mathrm{~h}$ in fresh DME containing $0.1 \%$ calf serum. Cells were used at passage numbers $8-18$.

DNA synthesis. Quiescent VSMC were labeled in the presence of $0.1 \%$ calf serum with $1 \mu \mathrm{Ci} / \mathrm{ml}$ [methyl- ${ }^{3} \mathrm{H}$ ] thymidine for $24 \mathrm{~h}$ with and without agent of interest. After labeling, cells were washed with cold PBS, trypsinized, and collected by centrifugation $(150 \mathrm{~g}$ for 5 min). The cell pellet was suspended in cold $10 \%$ TCA and vortexed vigorously to lyse the cells. After standing on ice for $20 \mathrm{~min}$, the cell lysate was passed through glass fibers and washed with cold 5\% TCA and $70 \%$ ethanol. The filter was then dried. Incorporated $\left[{ }^{3} \mathrm{H}\right]$ thymidine was measured in a liquid scintillation counter (LS 5000 TD; Beckman Instruments Inc., Fullerton, CA).

Cell number. Growth-arrested VSMC (35-mm dishes) were exposed to $20 \mu \mathrm{M}$ linoleic acid and/or $1 \mu \mathrm{M}$ 9-, or 13-HPODE for $96 \mathrm{~h}$. Cell numbers were then determined by trypan blue dye exclusion assay using a hemocytometer.

RNA blot analysis. Total cellular RNA from quiescent and agenttreated VSMC was isolated by the guanidine isothiocyanate-cesium chloride protocol of Chirgwin et al. (16). An equal amount of total cellular RNA (20 $\mu \mathrm{g})$ from quiescent and agonist-treated cells was size fractionated on $1 \%$ (wt/vol) agarose gel in $25 \mathrm{mM}$ Mops buffer ( $\mathrm{pH}$ 7.8) containing $1 \mathrm{mM}$ EDTA and $2 \%$ (wt/vol) formaldehyde. RNA was transferred to a Nytran membrane (Schleicher \& Schuell, Inc., Keene, $\mathrm{NH}$ ) according to the method of Thomas (17). RNA was crosslinked to the membrane using ultraviolet irradiation (Stratalinker; Stratagene Inc., La Jolla, CA). The cDNAs (an EcoRI and SstI fragment of 1.2-kb mouse c-fos cDNA; HindIII and NotI fragment of rat c-jun cDNA; and a full-length human c-myc and rat glyceraldehyde 3-phosphate dehydrogenase (GAPDH) cDNAs were labeled with $\left[\alpha-{ }^{32} \mathrm{P}\right]$ dCTP using a random primers labeling kit using the manufacturer's protocol (GIBCO BRL, Gaithersburg, MD). After a 4-h prehybridization in $50 \%(\mathrm{vol} / \mathrm{vol})$ formamide, $5 \times \mathrm{SSC}(1 \times \mathrm{SSC}=0.15 \mathrm{M} \mathrm{NaCl}$, $0.015 \mathrm{M}$ sodium citrate), $5 \times$ Denhardt's $(1 \times$ Denhardt's $=0.02 \%$ (wt $/$ vol) each of Ficoll, polyvinyl pyrrolidone, and bovine serum albumin), $50 \mathrm{mM}$ sodium phosphate $(\mathrm{pH} 6.5)$ and $250 \mu \mathrm{g} / \mathrm{ml}$ of sheared salmon sperm DNA at $42^{\circ} \mathrm{C}$, the Nytran membrane was hybridized in the above buffer containing $10 \%(\mathrm{wt} / \mathrm{vol})$ dextran sulfate and $1 \times 10^{6} \mathrm{cpm} / \mathrm{ml}$ of probe for $16 \mathrm{~h}$ at $42^{\circ} \mathrm{C}$. The Nytran membrane was washed three times in $2 \times \mathrm{SSC}, 0.2 \% \mathrm{SDS}\left(15 \mathrm{~min}\right.$ at $\left.25^{\circ} \mathrm{C}\right)$ and twice in $0.1 \times \mathrm{SSC}$, $0.1 \%$ SDS $\left(30 \mathrm{~min}\right.$ at $60^{\circ} \mathrm{C}$ ). The membrane was exposed to $\mathrm{x}$-ray film (X-Omat R; Eastman Kodak Co., Rochester, NY) with an intensifying screen at $-70^{\circ} \mathrm{C}$ for $4-6 \mathrm{~h}$. Densitometric analysis of the autoradiograms exposed in the linear range of film density was made using a $\mathrm{LaCie}$ scanner with National Institute of Health Image software.

Western blot analysis. Growth-arrested VSMC were incubated at $37^{\circ} \mathrm{C}$ for various times in the presence and absence of an appropriate agent. After incubation, medium was aspirated, cells rinsed with cold PBS, and frozen immediately in liquid nitrogen. Cells were then thawed

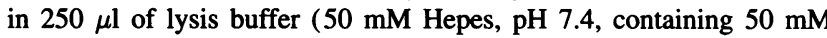
sodium pyrophosphate, $50 \mathrm{mM}$ sodium fluoride, $50 \mathrm{mM}$ sodium chloride, $5 \mathrm{mM}$ EDTA, $5 \mathrm{mM}$ EGTA, $2 \mathrm{mM}$ sodium orthovanadate, 0.5 $\mathrm{mM}$ PMSF, $10 \mu \mathrm{g} / \mathrm{ml}$ leupeptin, and $0.01 \%$ Triton X-100) and sonicated. Cell lysates were cleared by centrifugation at $14,000 \mathrm{rpm}$ for 20 $\min$ in a microfuge and protein content was determined using a reagent kit (Bradford; Bio-Rad Laboratories, Richmond, CA). Cell lysates containing equal amount of protein $(50 \mu \mathrm{g})$ from each condition were separated by SDS-PAGE (18) and transferred electrophoretically to nitrocellulose membranes. The membranes were probed with $1 \mu \mathrm{g} / \mathrm{ml}$ each of ERK-1 and ERK-2 anti-rabbit primary antibodies. After treating the membrane with peroxidase-conjugated goat anti-rabbit secondary antibodies, peroxidase activity was detected using ECL reagents (Amersham Corp.).

Immunocomplex MAP kinase assay. Cell lysates containing equal amounts of proteins $(500 \mu \mathrm{g})$ from each condition were incubated with
A

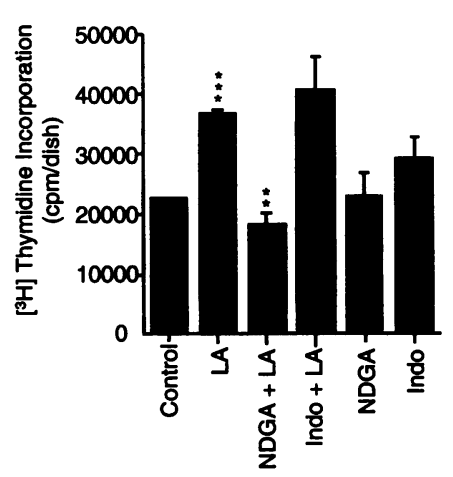

C

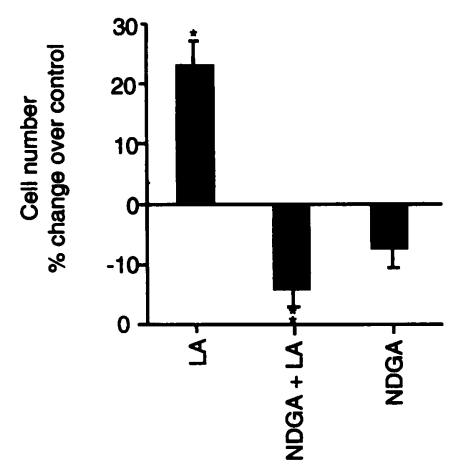

B

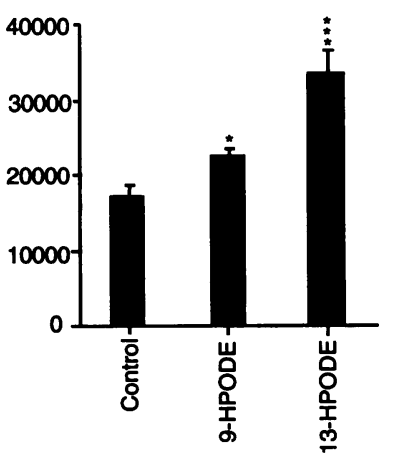

D

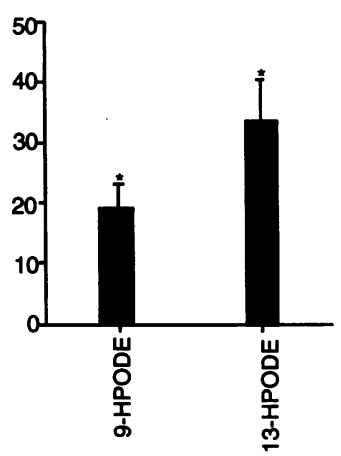

Figure 1. Linoleic acid and HPODEs induce VSMC growth. Thymidine incorporation $(A$ and $B)$ : Growth-arrested VSMC were treated with linoleic acid $(20 \mu \mathrm{M})$ or HPODEs $(1 \mu \mathrm{M})$ in the presence of $1 \mu \mathrm{Ci} /$ $\mathrm{ml}$ of $\left[{ }^{3} \mathrm{H}\right]$ thymidine and DNA synthesis was measured as trichloroacetic acid precipitable counts per min. Cell number $(C$ and $D)$ : Growtharrested VSMC were exposed to either linoleic acid $(L A)$ or HPODEs and $96 \mathrm{~h}$ later the cell number was determined by hemocytometer. Wherever appropriate, inhibitors were added $20 \mathrm{~min}$ before the addition of linoleic acid. Results are expressed as means \pm SD of three different experiments performed in triplicate in each experiment. $* * * P<0.01$ vs control; ${ }^{* *} P<0.01$ vs LA alone; ${ }^{*} P<0.05$ vs control.

$10 \mu \mathrm{l}$ each of ERK-1 (C-16) and ERK-2 (C-14) antiserum and $20 \mu \mathrm{l}$ of $50 \%(\mathrm{wt} / \mathrm{vol})$ protein A-Sepharose beads overnight at $4^{\circ} \mathrm{C}$. The immunoprecipitates were washed three times with lysis buffer and resuspended in lysis buffer. Reactions were carried out in a final volume of $50 \mu \mathrm{l}$ containing $50 \mathrm{mM} \beta$-glycerophosphate ( $\mathrm{pH} 7.3$ ), $1.5 \mathrm{mM}$ EGTA, $0.1 \mathrm{mM}$ sodium orthovanadate, $1 \mathrm{mM}$ DTT, $10 \mu \mathrm{M}$ calmidazolium, 10 $\mathrm{mM} \mathrm{MgCl}, 10 \mu \mathrm{g} / \mathrm{ml}$ leupeptin, $10 \mu \mathrm{g} / \mathrm{ml}$ aprotinin, $2 \mu \mathrm{g} / \mathrm{ml}$ pepstatin A, $1 \mathrm{mM}$ benzamidine, $0.3 \mathrm{mM}$ [ $\left.\gamma^{32} \mathrm{P}\right]$ ATP $(2,000 \mathrm{cpm} / \mathrm{pmol})$ and 0.5 $\mathrm{mg} / \mathrm{ml}$ myelin basic protein for $30 \mathrm{~min}$ at $37^{\circ} \mathrm{C}(19)$. Reactions were terminated by the addition of $50 \mu \mathrm{l}$ of cold $20 \%$ TCA. $50 \mu \mathrm{l}$ of the mix was then spotted on P-81 phosphocellulose filter. The filter was washed four times ( $5 \mathrm{~min}$ each) with $0.5 \%$ phosphoric acid and once with absolute ethanol. The filter was dried and the radioactivity was measured.

Statistics. Treatment effects were analyzed by Student's $t$ test. $P$ values $<0.05$ were considered to be significant.

\section{Results}

To determine the mitogenic effect of linoleic acid, VSMC were growth arrested and stimulated with linoleic acid $(20 \mu \mathrm{M})$ in the presence of $1 \mu \mathrm{Ci} / \mathrm{ml}\left[{ }^{3} \mathrm{H}\right]$ thymidine for $24 \mathrm{~h}$. Incorporation of $\left[{ }^{3} \mathrm{H}\right]$ thymidine into VSMC DNA was then measured. Linoleic acid increased VSMC DNA synthesis by $70 \%$ over control (Fig. $1 A$ ). Since linoleic acid metabolizes to HPODEs by the 
lipoxygenase pathway (20), to determine whether conversion of linoleic acid to HPODEs is required for induction of DNA synthesis, growth-arrested VSMC were stimulated with linoleic acid in the presence and absence of nordihydroguaiaretic acid (NDGA) $(10 \mu \mathrm{M})$, a potent inhibitor of the lipoxygenase system (21) and DNA synthesis was measured as described above. NDGA completely blocked the linoleic acid-induced DNA synthesis in VSMC. NDGA had no significant effect on seruminduced VSMC DNA synthesis (control, $17,721 \pm 2,135 \mathrm{cpm} /$ dish; serum, 209,329 \pm 963 ; NDGA + serum, 180,588 $\pm 1,197$; NDGA, 15,314 $\pm 1,910$; values are expressed as mean \pm SD), suggesting that its effect on linoleic acid-induced VSMC DNA synthesis is specific. Indomethacin $(10 \mu \mathrm{M})$, an inhibitor of the cyclooxygenase pathway (21), had no effect on linoleic acid-stimulated VSMC DNA synthesis. These results indicate that conversion of linoleic acid to HPODEs via the lipoxygenase system may be required for its observed effects on VSMC DNA synthesis. To determine if linoleic acid-induced DNA synthesis is associated with growth, VSMC numbers were measured 96 $\mathrm{h}$ after adding linoleic acid to growth-arrested cells. Consistent with thymidine incorporation data, linoleic acid treatment resulted in a $22 \%$ increase in VSMC number compared to untreated cells (Fig. $1 C$ ). As expected, increased numbers of VSMC in the presence of linoleic acid were suppressed by NDGA. Since this drug, besides inhibiting linoleic acid-induced VSMC growth, also blocked the basal growth of these cells to some extent, it is intriguing to suspect that lipoxygenase products of endogenous linoleic acid or arachidonic acid are modulators of basal growth in these cells. This observation is in agreement with the reported findings that lipoxygenase inhibitors exhibit antiproliferative activity $(4,5)$.

Since linoleic acid induced VSMC DNA synthesis and NDGA blocked this effect, we hypothesized that HPODEs, the lipoxygenase-dependent metabolites of linoleic acid, mediate this event. We tested this possibility by treating growth-arrested VSMC with 9-, or 13-HPODEs $(1 \mu \mathrm{M})$ for $24 \mathrm{~h}$ and determining VSMC DNA synthesis by $\left[{ }^{3} \mathrm{H}\right]$ thymidine incorporation. Both 9-, and 13-HPODEs increased VSMC DNA synthesis by 30 and $90 \%$, respectively (Fig. $1 B$ ). Cell counts showed an $18 \%$ and $32 \%$ increase by $9-$, and 13-HPODEs, respectively (Fig. $1 \mathrm{D}$ ). Together, these findings indicate that HPODEs mediate the effects of linoleic acid on VSMC growth.

Induced expression of c-fos, c-jun, and c-myc protooncogene mRNA is an early response to various growth stimuli (912). These protooncogenes encode for nuclear binding transcriptional factors $(9-12,22)$ and play an obligatory role in growth factor-induced cell division $(23,24)$. A recent study demonstrated that a null mutation at the c-jun locus causes embryonic lethality and retarded cell growth (25). To determine if these protooncogenes are also involved in linoleic acid-induced VSMC growth, we measured mRNA levels of these protooncogenes in VSMC in the presence of linoleic acid. Growtharrested VSMC were stimulated with linoleic acid $(20 \mu \mathrm{M})$ for various times and total cellular RNA was isolated. $20 \mu \mathrm{g}$ of total cellular RNA from linoleic acid-stimulated and nonstimulated VSMC was then analyzed for c-fos, c-jun, and c-myc transcripts by Northern blotting using the respective $\left[{ }^{32} \mathrm{P}\right]$-labeled cDNA probes. Linoleic acid stimulated expression of mRNAs of all three protooncogenes tested (Fig. 2). Maximal increases in cfos (40-fold), c-jun (20-fold), and c-myc (3-fold) mRNA levels occurred at $1 \mathrm{~h}$ of linoleic acid treatment. Expression of cfos and c-jun mRNAs in response to linoleic acid was found to be transient. Linoleic acid-induced expression of c-myc

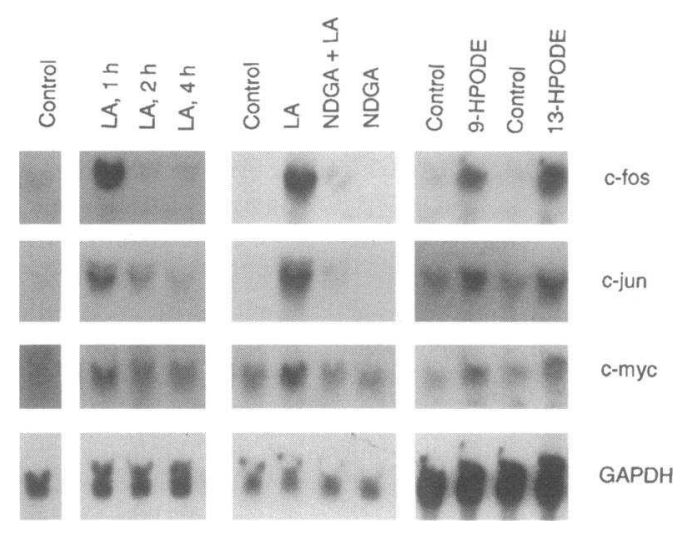

Figure 2. Linoleic acid ( $L A)$ and HPODEs stimulate expression of protooncogene mRNAs in VSMC. Growth-arrested VSMC were treated with indicated agents for $1 \mathrm{~h}$ (or for the time periods shown) and total cellular RNA was isolated. $20 \mu \mathrm{g}$ of total cellular RNA from each condition was then analyzed by Northern blotting for c-fos, c-jun, and $c-m y c$ transcripts using the respective $\left[{ }^{32} \mathrm{P}\right]$-labeled cDNA probes. Analysis of total cellular RNA for each condition from three separate experiments provided similar results. Results of one independent experiment are shown above.

mRNA, on the other hand, was persistent for at least $4 \mathrm{~h}$, although at lower levels than those at $1 \mathrm{~h}$ (Fig. 2).

Since linoleic acid-induced thymidine incorporation and cell numbers were sensitive to NDGA, we tested to see whether expression of c-fos, c-jun, and c-myc mRNA by linoleic acid was also blocked by NDGA. Growth-arrested VSMC were treated with linoleic acid $(20 \mu \mathrm{M})$ for $1 \mathrm{~h}$ in the presence and absence of NDGA $(10 \mu \mathrm{M})$ and total cellular RNA was isolated and analyzed for c-fos, c-jun, and c-myc mRNA levels as described above. NDGA completely blocked the linoleic acidinduced expression of these protooncogenes in VSMC (Fig. 2 ), a result which strengthens the argument that linoleic acid conversion via the lipoxygenase system is required to induce growth factor-like events in VSMC. In fact, stimulation for 1 $\mathrm{h}$ of growth-arrested VSMC with 9- and 13-HPODEs ( $1 \mu \mathrm{M})$ the primary lipoxygenase products of linoleic acid, resulted in similar increases in the mRNA levels of these protooncogenes (Fig. 2).

Recent results from several laboratories have elucidated how MAPK plays a critical role in the transmission of growth stimuli-elicited mitogenic signals in various cell types $(13,14)$. In the mitogenic signaling pathway, activation of these kinases occurs before the induction of expression of c-fos, c-jun, and c-myc mRNAs. These findings stimulated our examination of the activation of these kinases by linoleic acid and its metabolites in VSMC. Growth-arrested VSMC were stimulated with linoleic acid $(20 \mu \mathrm{M})$ for varying times and cell lysates were prepared. Equal amounts of protein from linoleic acid-treated and untreated samples were then assayed for MAPK activities. MAPK activation was determined by gel-shift and immunocomplex kinase assays. The gel-shift assay was selected because phosphorylated and activated MAPK migrate slower on SDSPAGE than the nonphosphorylated inactive form (26). In the immunocomplex kinase assay, MAPK are immunoprecipitated and their activities are measured using myelin basic protein as a substrate in these immunocomplexes. As shown in Fig. 3, $A$ and $B$, linoleic acid activated MAPK in VSMC, which was apparent at $5 \mathrm{~min}$, peaked at $10 \mathrm{~min}$ (threefold) and dropped 
B

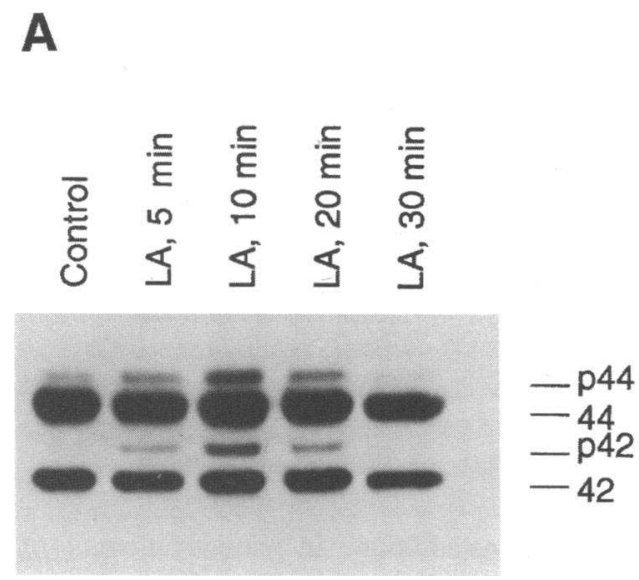

Figure 3. Linoleic acid ( $L A)$ activates MAPK in VSMC. Growtharrested VSMC were treated with linoleic acid (20 $\mu \mathrm{M})$ for varying times and cell lysates were prepared. MAPK were detected in cell lysates by Western blotting $(A)$ as described in Methods. Phosphorylated and activated MAPK migrate slower on SDSPAGE than the nonphosphorylated inactive form. p42 and p44 are phosphorylated forms of 42 and $44 \mathrm{kD}$ MAPK, respectively. MAPK activity was measured in cell lysates of VSMC treated identically to those in $A$, using myelin basic protein as substrate $(B)$. $(A)$ Results are representative of one experiment and these results were reproduced in two separate experiments. Results in $B$ are means $\pm S D$ of three separate experiments performed in duplicates each time. $* * P<0.01$ and $* P$ $<0.05$ vs control. thereafter, nearly reaching baseline by $30 \mathrm{~min}$. Furthermore, linoleic acid-induced MAPK activation was found to be sensitive to NDGA (Fig. 4, $A$ and $B$ ). Treatment of growth-arrested VSMC with 9- and/or 13-HPODE $(1 \mu \mathrm{M})$ for $10 \mathrm{~min}$ also activated these kinases in VSMC (Fig. 5, $A$ and $B$ ).

\section{Discussion}

The main significance of this study is that linoleic acid is a mitogen for VSMC. Several observations support this conclusion. First, linoleic acid induced VSMC DNA synthesis and its number. Second, linoleic acid stimulated early growth-response events such as induced expression of c-fos, c-jun, and c-myc mRNA and activation of MAPK. Linoleic acid-induced growth events in VSMC appeared to be mediated by HPODEs as these activities were suppressed by NDGA, a potent inhibitor of the lipoxygenase system and were stimulated by HPODEs, the lipoxygenase products of linoleic acid. These findings combined with the fact that linoleic acid and its metabolites stimulate growth in hepatoma cells (1), and enhance the mitogenic effect of EGF in mammary epithelial cells and fibroblasts (2, 3 ) imply that these lipid molecules act as growth modulators of several cell types, now including VSMC. The ability of linoleic acid and its metabolites to stimulate early growth response events such as induced expression of c-fos, c-jun, and c-myc mRNA and activation of MAPK strongly suggest their role in regulating VSMC growth. Although the exact mechanism by which linoleic acid and its metabolites transmit mitogenic sig-

B

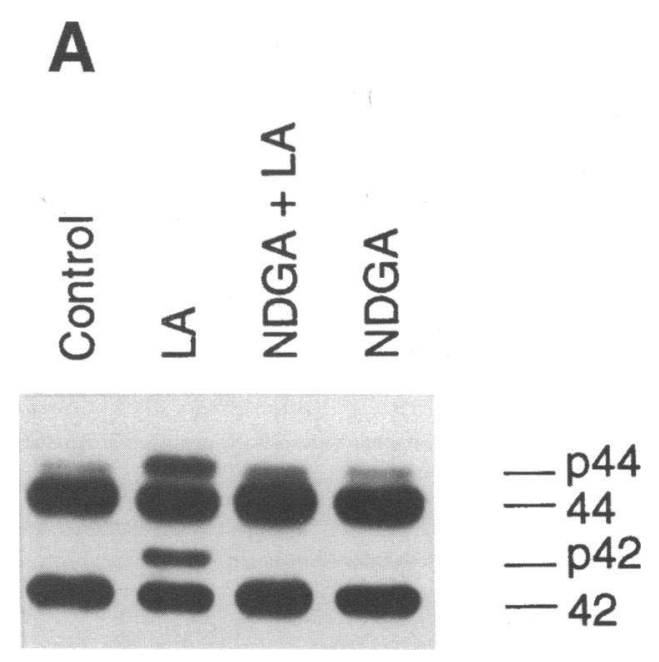

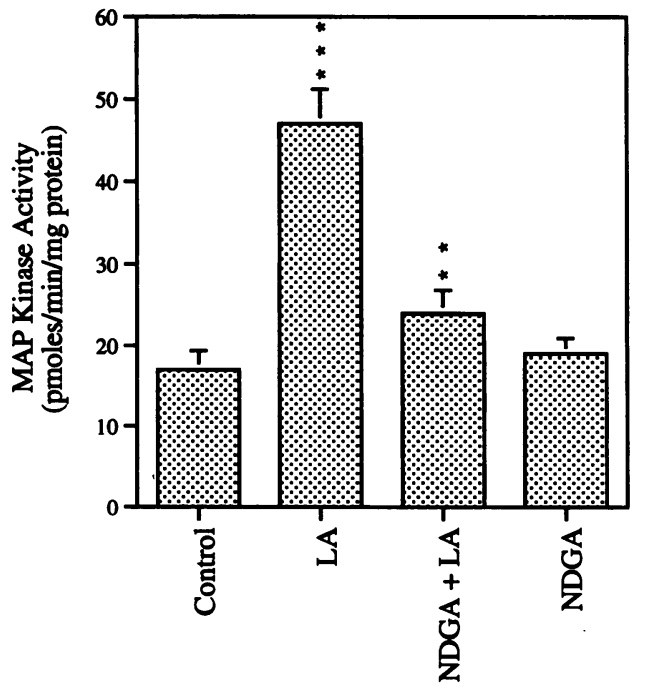

Figure 4. NDGA blocks linoleic acid $(L A)$-induced activation of MAPK in VSMC. Growth-arrested VSMC were exposed to 20 $\mu \mathrm{M}$ linoleic acid for $10 \mathrm{~min}$ in the presence and absence of $10 \mu \mathrm{M}$ NDGA and cell lysates were prepared and analyzed for MAPK activities as described in Fig. 3. ( $A$ ) Results are representative of one experiment and these results were reproduced in two separate experiments. Results in $B$ are means \pm SD of three separate experiments performed in duplicates each time. $* * * P<0.01$ vs control; $* * P<0.05$ vs LA alone. 
A

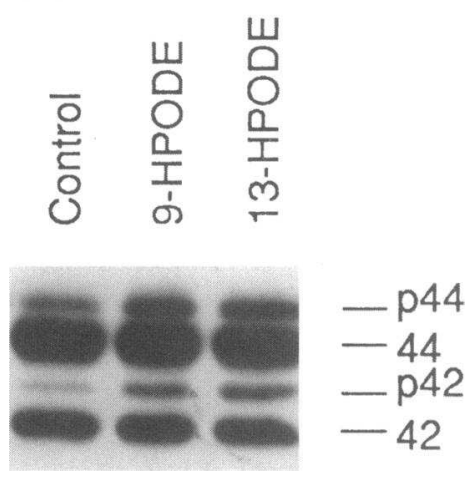

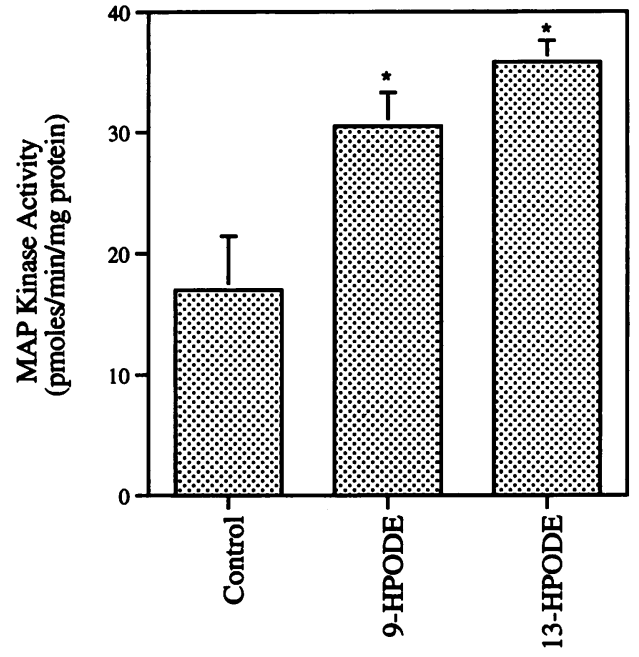

Figure 5. HPODEs stimulate activation of MAPK in VSMC. Conditions were the same as described in Fig. 3 except that cells were treated with $1 \mu \mathrm{M}$ 9- or 13HPODE for 10 min. $(A)$ Results are representative of one experiment and these results were reproduced in two separate experiments. Results in $B$ are means \pm SD of three separate experiments performed in duplicates each time. $* P<0.05$ vs control. nals in VSMC is unclear, our findings provide initial evidence that these molecules possess the ability to induce expression of c-fos, c-jun, and c-myc mRNA and stimulate activation of MAPK in VSMC; events that are required for cells to grow in response to growth stimuli $(9-15,22-25)$. Previous studies have demonstrated a requirement for activator protein-1 (AP1 ) activity in modulating growth in vivo and in vitro (25). Since linoleic acid and HPODEs were found to be modest inducers of c-fos, and c-jun mRNAs, the protein products of which constitute the transcriptional factor AP-1, it is likely that AP-1 plays a role in the growth stimulated by these agents. In fact, linoleic acid and HPODEs induced AP-1 activity markedly in VSMC (Rao, G. N., unpublished observations). Future studies on the role of AP-1 in linoleic acid and HPODEs-induced gene transactivation should address whether AP-1 mediates the growth events induced by these lipid molecules.

A large body of evidence indicates that MAPK play an important role in transmitting mitogenic signals in response to growth factors $(13,14,27-31)$. MAPK phosphorylate and activate nuclear binding proteins such as c-fos, c-jun, and c$m y c$, which, in turn modulate transcription of target genes (3234). Since linoleic acid and HPODEs are capable of activating MAPK in VSMC, it is possible that these kinases are involved in lipid molecule-induced propagation of mitogenic signals. Activation of MAPK by growth factors requires an upstream kinase cascade of activities such as "Ras-Raf-MEK" in this order (13, 14, 27-31). Mitogenically active lipids such as phosphatidic acid, arachidonic acid, and linoleic acid can reportedly activate ras via inhibition of guanosine triphosphatase activating protein activity (35). Recently we reported that arachidonic acid activates MAPK and protein kinase C (PKC) mediates this effect (36). PKC has also been shown to activate ras (37). Together these findings lead us to speculate that linoleic acid and HPODEs-induced activation of MAPK may be mediated by a kinase cascade that includes ras and PKC. Future studies, however, are required to elucidate the exact upstream kinases associated with linoleic acid and HPODEs-induced activation of MAPK and growth in VSMC.

The present findings have important implications in the pathogenesis of atherosclerosis. Steinberg and associates have demonstrated that 15-lipoxygenase protein deposits in athero- sclerotic plaque (38). In addition, increased amounts of HODEs, the lipoxygenase products of linoleic acid, have also been reported in atherosclerotic arteries. Because HPODEs appear to be mitogenic to VSMC, these molecules could account, at least partially, for the observed growth of VSMC in atherosclerosis. In conclusion, our results provide the first molecular evidence for the mitogenic role of linoleic acid and its metabolites, HPODEs, in VSMC. Therefore, strategies targeting the inhibition of the oxidative metabolism of polyunsaturated fatty acids such as linoleic acid may be therapeutically beneficial in modifying the atherogenic process.

\section{Acknowledgments}

We thank Drs. Tom Curran and Mikael Karin for providing the c-fos and c-jun plasmids, respectively. We also thank Joann Aaron for editorial assistance and Barbara L. Murphy for assistance with typing.

\section{References}

1. Keller, T., C. S. Barker, and S. Sorof. 1992. Specific growth stimulation by linoleic acid in hepatoma cell lines transfected with the target protein of a liver carcinogen. Proc. Natl. Acad. Sci. USA. 89:4830-4834.

2. Bandyopadhyay, G. K., W. Imagawa, D. Wallace, and S. Nandi. 1987. Linoleate metabolites enhance the in vitro proliferative response of mouse mam mary epithelial cells to epidermal growth factor. J. Biol. Chem. 262:2750-2756.

3. Glasgow, W. C., C. A. Afshari, J. C. Barrett, and T. E. Eling. 1992. Modulation of the epidermal growth factor mitogenic response by metabolites of linoleic and arachidonic acid in Syrian hamster embryo fibroblasts. J. Biol. Chem. 267:10771-10779.

4. Miller, A. M., M. K. Cullen, S. M. Kobb, and R. S. Wenier. 1989. Effects of lipoxygenase and glutathione pathway inhibitors on leukemic cell line growth. J. Lab. Clin. Med. 113:355-361.

5. Ralph, R. K., and S. Wojcik. 1990. Inhibitors of lipoxygenase have antiproliferative effects on P815 murine mastocytoma cells. Cancer Lett. 49:181-185.

6. Baer, A. N., P. B. Costello, and F. A. Green. 1990. Free and esterified 13(R,S)-hydroxyoctadecadienoic acids: principal oxygenase products in psoriatic skin scales. J. Lipid Res. 31:125-130.

7. Ross, R. 1993. The pathogenesis of atherosclerosis: a perspective for the 1990s. Nature (Lond.). 362:801-809.

8. Wang, T., and W. S. Powell. 1991. Increased levels of monohydroxy metabolites of arachidonic acid and linoleic acid in LDL and aorta from atherosclerotic rabbits. Biochem. Biophys. Acta. 1084:129-138.

9. Lau, L. F., and D. Nathans. 1987. Expression of a set of growth-related immediate early genes in BALB/c 3T3 cells: coordinate regulation with c-fos or c-myc. Proc. Natl. Acad. Sci. USA. 84:1182-1186. 
10. Curran, T., and B. R. J. Franza. 1988. Fos and jun: the AP-1 connection. Cell. 55:395-397.

11. Angel, P., and M. Karin. 1991. The role of jun, fos and the AP-1 complex in cell proliferation and transformation. Biochem. Biophys. Acta. 1072:129-157.

12. Kaczmarek, L., J. K. Hyland, R. Wat, M. Rosenberg, and R. Baserga 1985. Microinjected c-myc as a competence factor. Science (Wash. DC). 228:1313-1315

13. Davis, R. J. 1993. The mitogen-activated protein kinase signal transduction pathway. J. Biol. Chem. 268:14553-14556.

14. Cobb, M. H., T. G. Boulton, and D. J. Robbins. 1991. Extracellular signalregulated kinases: ERKs in progress. Cell Regul. 2:965-978.

15. Travo, P., G. Barrett, and G. Burnstock. 1980. Differences in proliferation of primary cultures of vascular smooth muscle cells taken from male and female rats. Blood Vessels. 17:110-116.

16. Chirgwin, J. M., A. E. Przybyla, R. J. MacDonald, and W. J. Rutter 1979. Isolation of biologically active ribonucleic acid from sources enriched in ribonuclease. Biochemistry. 18:5294-5299.

17. Thomas, P. S. 1980 . Hybridization of denatured RNA and small DNA fragments transferred to nitrocellulose. Proc. Natl. Acad. Sci. USA. 77:52015205 .

18. Laemmli, U. K. 1970. Cleavage of structural proteins during the assembly of the head of bacteriophage T4. Nature (Lond.). 227:680-685.

19. Ahn, N. G., J. E. Weiel, C. P. Chan, and E. G. Krebs. 1990. Identification of multiple epidermal growth factor-stimulated protein serine/threonine kinases from Swiss 3T3 cells. J. Biol. Chem. 265:11487-11494.

20. Funk, C. D., and W. S. Powell. 1985. Release of prostaglandins and monohydroxy and trihydroxy metabolites of linoleic and arachidonic acids by adult and fetal aortae and ductus arteriosus. J. Biol. Chem. 260:7481-7488.

21. Sellmayer, A., W. M. Uedelhoven, P. C. Weber, and J. V. Bonventre. 1991. Endogenous non-cyclooxygenase metabolites of arachidonic acid modulate growth and mRNA levels of immediate-early response genes in rat mesangial cells. J. Biol. Chem. 266:3800-3807.

22. Kouzarides, T., and E. Ziff. 1989. Behind the $f$ os and $j u n$ leucine zipper. Cancer Cells A Mon. Rev. 1:71-74.

23. Holt, J. T., T. V. Gopal, A. D. Moulton, and A. W. Nienhuis. 1986 Inducible production of c-fos antisense RNA inhibits 3T3 cell proliferation. Proc. Natl. Acad. Sci. USA. 83:4794-4798.

24. Wickstrom, E. L., T. A. Bacon, A. Gonzalez, D. L. Freeman, G. H. Lyman, and E. Wickstrom. 1988. Human promyelocytic leukemia HL-60 cell proliferation and c-myc protein expression are inhibited by an antisense pentadecadeoxynucleotide targeted against c-myc mRNA. Proc. Natl. Acad. Sci. USA. 85:1028-1032.

25. Johnson, R. S., B. V. Lingen, V. E. Papaioannou, and B. M. Spiegelman 1993. A null mutation at the c-jun locus causes embryonic lethality and retarded cell growth in culture. Genes \& Dev. 7:1309-1317.
26. Leevers, S. J., and C. J. Marshall. 1992. Activation of extracellular signalregulated kinase, ERK2, by p21ras oncoprotein. EMBO (Eur. Mol. Biol. Org.) J. 11:569-574.

27. Macdonald, S. G., C. M. Crews, L. Wu, J. Driller, R. Clark, R. L. Erikson, and F. McCormick 1993. Reconstitution of the Raf-1-MEK-ERK signal transduction pathway in vitro. Mol. Cell. Biol. 13:6615-6620.

28. Kolch, W., G. Heidecker, P. Lloyd, and U. R. Rapp. 1991. Raf-1 protein kinase is required for growth of induced NIH/3T3 cells. Nature (Lond.). 349:426428.

29. Huang, W., A. Alessandrini, C. M. Crews, and R. L. Erikson. 1993. Raf1 forms a stable complex with Mek 1 and activates Mek 1 by serine phosphorylation. Proc. Natl. Acad. Sci. USA. 90:10947-10951.

30. Kyriakis, J. M., H. App, X. F. Zhang, P. Banerjee, D. L. Brautigan, U. R. Rapp, and J. Avruch. 1992. Raf-1 activates MAP kinase kinase. Nature (Lond.). 358:417-421.

31. Gardner, A. M., R. R. Vaillancourt, and G. L. Johnson. 1993. Activation of mitogen-activated protein kinase/extracellular signal-regulated kinase kinase by $\mathrm{G}$ protein and tyrosine kinase oncoproteins. J. Biol. Chem. 268:17896-17901.

32. Alvarez, E., I. C. Northwood, F. H. Gonzalez, D. H. Latour, A. Seth, C. Abate, T. Curran, and R. J. Davis. 1991. Pro-Leu-Ser/Thr-Pro is a consensus primary sequence for substrate protein phosphorylation. Characterization of the phosphorylation of c-myc and c-jun proteins by an epidermal growth factor receptor threonine 669 protein kinase. J. Biol. Chem. 266:15277-15285.

33. Gille, H., A. D. Sharrocks, and P. E. Shaw. 1992. Phosphorylation of transcription factor $\mathrm{p} 62^{\mathrm{TCF}}$ by MAP kinase stimulates ternary complex formation at c-fos promoter. Nature (Lond.). 358:414-417.

34. Marais, R., J. Wayne, and R. Treisman. 1993. The SRF accessory protein ELK-1 contains a growth-factor regulated transcription domain. Cell 73:381-393.

35. Tsai, M. H., C. L. Yu, F. S. Wei, and D. W. Stacey. 1988. The effect of GTPase activating protein upon ras is inhibited by mitogenically responsive lipids. Science (Wash. DC). 243:522-526.

36. Rao, G. N., A. S. Baas, W. C. Glasgow, T. E. Eling, M. S. Runge and R. W. Alexander. 1994. Activation of mitogen-activated protein kinases by arachidonic acid and its metabolites in vascular smooth muscle cells. J. Biol. Chem. 269:32586-32591.

37. Mulcahy, L. S., M. R. Smith, and D. W. Stacey. 1985. Requirement for ras-protooncogene function during serum-stimulated growth of NIH/3T3 cells. Nature (Lond.). 313:241-243.

38. Herttuala, S. Y., M. E. Rosenfeld, S. Parthasarathy, E. Sigal, T. Sarkioja J. L. Witztum, and D. Steinberg. 1991. Gene expression in macrophage-rich human atherosclerotic lesions: 15-lipoxygenase and acetyl LDL receptor mRNA colocalize with oxidation-specific lipid-protein adducts. J. Clin. Invest. 87:11461152. 